\title{
Bone Morphogenetic Protein Signaling in the Developing Telencephalon Controls Formation of the Hippocampal Dentate Gyrus and Modifies Fear-Related Behavior
}

\author{
Giuliana Caronia, Jennifer Wilcoxon, Polina Feldman, and Elizabeth A. Grove \\ Department of Neurobiology, University of Chicago, Chicago, Illinois 60637
}

\begin{abstract}
The cortical hem is an embryonic signaling center that generates bone morphogenetic proteins (BMPs) and acts as an organizer for the hippocampus. The role of BMP signaling in hippocampal neurogenesis, however, has not been established. We therefore generated mice that were deficient in Bmprlb constitutively, and deficient in Bmprla conditionally in the dorsal telencephalon. In double mutant male and female mice, the dentate gyrus (DG) was dramatically smaller than in control mice, reflecting decreased production of granule neurons at the peak period of DG neurogenesis. Additionally, the pool of cells that generates new DG neurons throughout life was reduced, commensurate with the smaller size of the DG. Effects of diminished BMP signaling on the cortical hem were at least partly responsible for these defects in DG development. Reduction of the DG and its major extrinsic output to CA3 raised the possibility that the DG was functionally compromised. We therefore looked for behavioral deficits in double mutants and found that the mice were less responsive to fear- or anxiety-provoking stimuli, whether the association of the stimulus with fear or anxiety was learned or innate. Given that no anatomical defects appeared in the double mutant telencephalon outside the DG, our observations support a growing literature that implicates the hippocampus in circuitry mediating fear and anxiety. Our results additionally indicate a requirement for BMP signaling in generating the dorsalmost neuronal lineage of the telencephalon, DG granule neurons, and in the development of the stem cell niche that makes neurons in the adult hippocampus.
\end{abstract}

\section{Introduction}

The embryonic telencephalon contains dorsal midline signaling centers, the roofplate and cortical hem, which secrete Wnt proteins and bone morphogenetic proteins (BMPs) and contribute to telencephalic patterning (Furuta et al., 1997; Grove et al., 1998; Hébert et al., 2002; Cheng et al., 2006; Fernandes et al., 2007; Mangale et al., 2008). Substantial evidence implicates Wnt signaling in specification and proliferation of hippocampal neurons (Galceran et al., 2000; Lee et al., 2000; Li et al., 2005; Machon et al., 2007; Mangale et al., 2008), but the contribution of BMP signaling to the development of the neuronal populations of the hippocampus remains unclear.

A promising approach to determining the telencephalic role of BMP signaling has been to generate mice deficient in BMP receptor activity (Hébert et al., 2002; Fernandes et al., 2007). $\mathrm{BMP}$ receptors are heterodimers of type I and type II subunits (Chen et al., 2004). Genetically removing type I components reduces BMP signaling effectively in the developing CNS (Wine-Lee et al., 2004; Qin et al., 2006; Fernandes et al., 2007).

Received Feb. 1, 2010; revised March 10, 2010; accepted March 23, 2010.

This work was supported by National Institute of Mental Health Grant R37 H059962 (E.A.G.). We thank K. R. Jones, K. M. Lyons, A. P. McMahon, and Y. Mishina for mouse lines, P. Mason and C. W. Ragsdale for comments on this manuscript, X. Zhuang for providing behavioral testing equipment and advice, and V. Bindokas for assistance with three-dimensional reconstruction of the hippocampus.

Correspondence should be addressed to Elizabeth A. Grove, Department of Neurobiology, University of Chicago, Chicago, IL 60637. E-mail: egrove@bsd.uchicago.edu.

DOI:10.1523/JNEUROSCI.0550-10.2010

Copyright $\odot 2010$ the authors $\quad 0270-6474 / 10 / 306291-11 \$ 15.00 / 0$
BMPR1a and BMPR1b are separately required in developmental processes such as gastrulation or chondrogenesis (Mishina et al., 1995; Yi et al., 2000; Ahn et al., 2001; Jamin et al., 2002; Andl et al., 2004; Ovchinnikov et al., 2006). In several studies of CNS development, however, each receptor can compensate for the loss of the other (Hébert et al., 2003; Wine-Lee et al., 2004; Fernandes et al., 2007). Consistent with this functional redundancy, deleting genes encoding single type I subunits has disappointingly modest effects in the telencephalon, which expresses three type I BMP receptor genes, Bmprla/Alk3, Bmpr1b/Alk6, and Alk2 (GENSAT, public domain) (Fig. 1A-C). Deleting $B m p r 1 b$ causes no obvious defects (Yi et al., 2000). Conditional deletion of Bmprla in the early embryonic telencephalon results in loss of the telencephalic choroid plexus epithelium (CPe) (Hébert et al., 2002), a non-neuronal structure, and to date no effects of deleting Alk2 selectively in the telencephalon have been reported.

In contrast, compound mutant mice show an extreme phenotype. Loss of Bmpr1b and conditional deletion of Bmprla before the forebrain vesicle has closed causes holoprosencephaly (Fernandes et al., 2007). The entire dorsal telencephalic midline is disrupted; moreover, the embryo dies in midgestation (Fernandes et al., 2007), making it impossible to distinguish the loss of specific dorsal neuron types.

We aimed at an intermediate effect on telencephalic development by generating Bmprla;Bmprlb mutant mice in which Bmprla was deleted by Cre-lox recombination after neural tube closure. These mice, henceforth, "double mutants," were not holoprosencephalic and lived into adulthood. Double mutants 
showed an abnormally small hippocampal dentate gyrus (DG). Specifically reduced were the granule cells of the DG, and the pool of cells set aside to generate new granule neurons in the adult. The mossy fibers bundles that represent the major extrinsic output from the DG to CA3 were also diminished. We investigated the mechanisms by which reduction of BMP signaling caused a smaller DG and the behavioral consequences of an abnormal DG in double mutant mice.

\section{Materials and Methods}

Mouse lines. The Institutional Animal Care and Use Committee of the University of Chicago approved all protocols; mice were used according to National Institutes of Health guidelines. Mice carrying mutant alleles of Bmprla or Bmprlb were gifts from Y. Mishina (University of Michigan, Ann Arbor, MI) (Mishina et al., 1995, 2002) and K. M. Lyons (University of California, Los Angeles, Los Angeles, CA) (Yi et al., 2000). The Emx1(IRES)Cre line was provided by Dr. K. R. Jones (Gorski et al., 2002). A mouse line deficient in Wnt3a was provided by Dr. A. C. P. McMahon (Harvard University, Cambridge, MA) (Takada et al., 1994).

Introduction of loxP sites into the Bmprla locus has been described previously, and Cre-dependent recombination of the resulting Bmprla $a^{f x}$ allele generates a null allele (Mishina et al., 2002). Tissue from the tail and telencephalon was collected from embryos, pups, and adult mice, and two sets of primer pairs were used with PCR to amplify either a $180 \mathrm{bp}$ fragment that indicated Cre-dependent recombination of the Bmprla $a^{f x}$ allele or a $190 \mathrm{bp}$ fragment from the Bmprla null allele (Mishina et al., 2002). Primers used to identify the null allele of $B m p r l b$ were as previously described (Yi et al., 2000). The mutant alleles of Bmprla or Bmpr1b used in the present study have been used extensively in studies cited above, and others, and found to reduce BMP receptor function in the mouse embryo (Ahn et al., 2001; Jamin et al., 2002; Andl et al., 2004; Wine-Lee et al., 2004; Ovchinnikov et al., 2006; Qin et al., 2006; Fernandes et al., 2007; Samanta et al., 2007). Equally, the Emx1(IRES)Cre line has been demonstrated to produce highly efficient Cre-lox recombination in the dorsal telencephalon (Gorski et al., 2002, 2003; Li et al., 2003; Baquet et al., 2004; Yoshida et al., 2006; Cocas et al., 2009).

Tissue processing. For analysis of the forebrain, brain sections were taken from double mutants and control mice from embryonic day 11.5 (E11.5) to 1 year of age. Structural, gene expression, cell proliferation, and cell death comparisons between the brains of double mutant mice and controls were based on at least three brains per group per age for each gene, protein product, or histochemical assay. Fixed brains were sectioned using a Leica 2000 sliding microtome and processed for in situ hybridization, histochemistry, and immunohistochemistry (IHC). Images were captured with a Zeiss Axioskop microscope, Axiovision camera, and software.

Expression patterns of Alk2, Bmprla, Bmpr1b, Ctgf, Cxcr4, Ephb1, Etv1, Fezf2, Fz10, Id3, Msx2, Prox1, Rorb, Pou3f1/SCIP, Sorl1, Tbr1, Ttr1, and $W n t 3 a$ genes were visualized by nonradioactive in situ hybridization (Grove et al., 1998) to assess development of the cortical hem, dentate gyrus, other regions of the hippocampus, and overall brain structure.

For immunohistochemistry, primary antibodies were as follows: antiphospho-Smad1 (Ser463/465)/Smad5 (Ser463/465)/Smad8 (Ser426/ 428) rabbit polyclonal antibody (1:50; Cell Signaling Technology), antiphosphohistone H3 (PH3) (Ser10) rabbit polyclonal antibody (1:200; Millipore), anti-calbindin D-28K rabbit polyclonal antibody (1:250; Millipore Bioscience Research Reagents), anti-neuronal nuclei (NeuN) mouse monoclonal antibody (1:10; Millipore), anti-5-bromo-2-deoxyuridine (BrdU) mouse monoclonal antibody (1:75; BD Biosciences) for IHC and anti-BrdU mouse monoclonal antibody (1:50; Serotec) for immunofluorescence, anti-tyrosine hydroxylase (TH) antibody (1:5000; BD Biosciences), anti- $\beta$-tubulin (Tuj1) (1:500; Covance), anti-Axin2 rabbit polyclonal antibody (1:5000; Abcam), anti-Olig2 rabbit polyclonal antibody (1:1000; Abcam), anti-(cleaved) caspase 3 rabbit polyclonal antibody (1:200; Cell Signaling), anti-Dickkopf1 (DKK1) rabbit polyclonal antibody (1:2000; Santa Cruz Biotechnology), anti-calretinin rabbit polyclonal antibody (1:1000; Millipore), and anti-Acvr1 (ALK2) rabbit polyclonal antibody (1:2000; Novus Biologicals).
To survey brain structure overall, histological assays included AChE (acetylcholinesterase) histochemistry, a standard way to identify brain subdivisions (Paxinos et al., 1991) and NeuN and $\beta$-tubulin IHC, which allowed determination of neuron density and additional identification of specific structures and cell groups. Caspase-3 IHC was used to identify apoptotic cells, and PH3 IHC and BrdU labeling, to identify cells in division. To label newborn neurons at postnatal day 5 (P5), pups were injected with a single dose of $\mathrm{BrdU}$ ( $200 \mu \mathrm{g} / \mathrm{g}$ body weight) $24 \mathrm{~h}$ before killing. To label dividing cells in the adult DG, mice were injected once daily for $7 \mathrm{~d}$ before killing.

Quantification of neurogenesis and cell proliferation. BrdU-immunoreactive (IR) or PH3-IR DG cells were counted in 10 sections/brain in one $0.04 \mathrm{~mm}^{2}$ field/section in neonatal brains, and two $0.05 \mathrm{~mm}^{2}$ fields/ section in young adult brains. In neonates, square fields were centered on the DG hilus, and in the adult, a pair of rectangular fields were centered on the inner margin of each blade of the DG, the subgranular zone (SGZ). One-tailed $t$ tests were used to test for difference between cell density scores in double mutant $(n=3)$ and control mice $(n=3)$ brains.

Quantification of gcl area. Three young adult double mutant brains and littermate controls from three different litters were analyzed. From each brain, 12 coronal sections $20 \mu \mathrm{m}$ thick were selected evenly spaced along the anterior/posterior $(\mathrm{A} / \mathrm{P})$ axis of the forebrain. Images of the sections were obtained as above, and the area of the adult granule cell layer ( $\mathrm{gcl}$ ) of the DG was measured using ImageJ. A contour was drawn around the gcl in each section and the area inside the contour measured in pixels. From each matched pair of mutant and control brains, paired area measurements were obtained at 12 different A/P levels through the DG. Pooled $\mathrm{gcl}$ area measurements were compared between double mutants and controls with the paired two-sample $t$ test.

Behavioral testing overview. Mice were 12 weeks of age when testing began. Tests were conducted in the following sequence: home cage activity, open-field test, fear conditioning, Morris water maze (MWM), elevated plus maze, startle response, and T-maze. One week of rest was given between tasks.

Home cage activity. Mice were single-housed in cages placed onto a Stoelting activity meter (Grailhe et al., 1999). Activity was monitored continuously for $48 \mathrm{~h}$.

Open-field test. (Beeler et al., 2006). Each mouse was placed in an acrylic open-field chamber (MED Associates). Infrared beams recorded the animal's location and path (locomotor activity) as well as the number of rearing movements. Data were collected in $5 \mathrm{~min}$ bins during a $1 \mathrm{~h}$ trial.

Fear conditioning. This one-trial training protocol (Tang et al., 1999) used a fear-conditioning working station (Coulbourn Instruments). Mice were individually put into the shock chamber and allowed to explore the environment for $150 \mathrm{~s}$. A tone $(90 \mathrm{~dB} ; 2800 \mathrm{~Hz})$ (conditioned stimulus) then sounded for $30 \mathrm{~s}$, and during the last $2 \mathrm{~s}$ a footshock $(0.8$ $\mathrm{mA}$ ) was delivered (unconditioned stimulus). A retention test was conducted $24 \mathrm{~h}$ after training. For contextual conditioning, mice were put back into the chamber where they had received the shock on the previous day, and freezing responses were recorded for $4 \mathrm{~min}$. For cued conditioning, mice were put into a novel chamber for $3 \mathrm{~min}$. Then the same tone used during the training session was delivered for another 3 min. Freezing was recorded in both pretone and during-tone periods.

Morris water maze. A white acrylic pool (100 cm diameter) was filled so that the water line was $\sim 20 \mathrm{~cm}$ below the lip of the pool. For hiddenplatform trials, nontoxic white paint (Reeves and Poole Group) was added to the water, and the platform (diameter, $8 \mathrm{~cm}$ ) submerged $1 \mathrm{~cm}$ below the surface and kept in one location for all training trials. Mice were given four trials on 6 consecutive days; on the seventh day, the platform was removed from the pool for a probe trial in which the time spent in the former platform quadrant was measured. Movements were recorded using EthoVision software (Noldus).

Elevated plus maze. The elevated plus maze (EPM) had four arms measuring $30 \mathrm{~cm}$ in length and $7 \mathrm{~cm}$ in width, elevated $55 \mathrm{~cm}$ above the floor (Beeler et al., 2006). Two arms had $15 \mathrm{~cm}$ walls enclosing all but the top; the other two arms were open. Animals were placed in the central platform and allowed to explore the maze for $5 \mathrm{~min}$. Mice were recorded by a video camera placed above the mice and the following were scored: total entries (number of entries into an arm), open arm entry index 

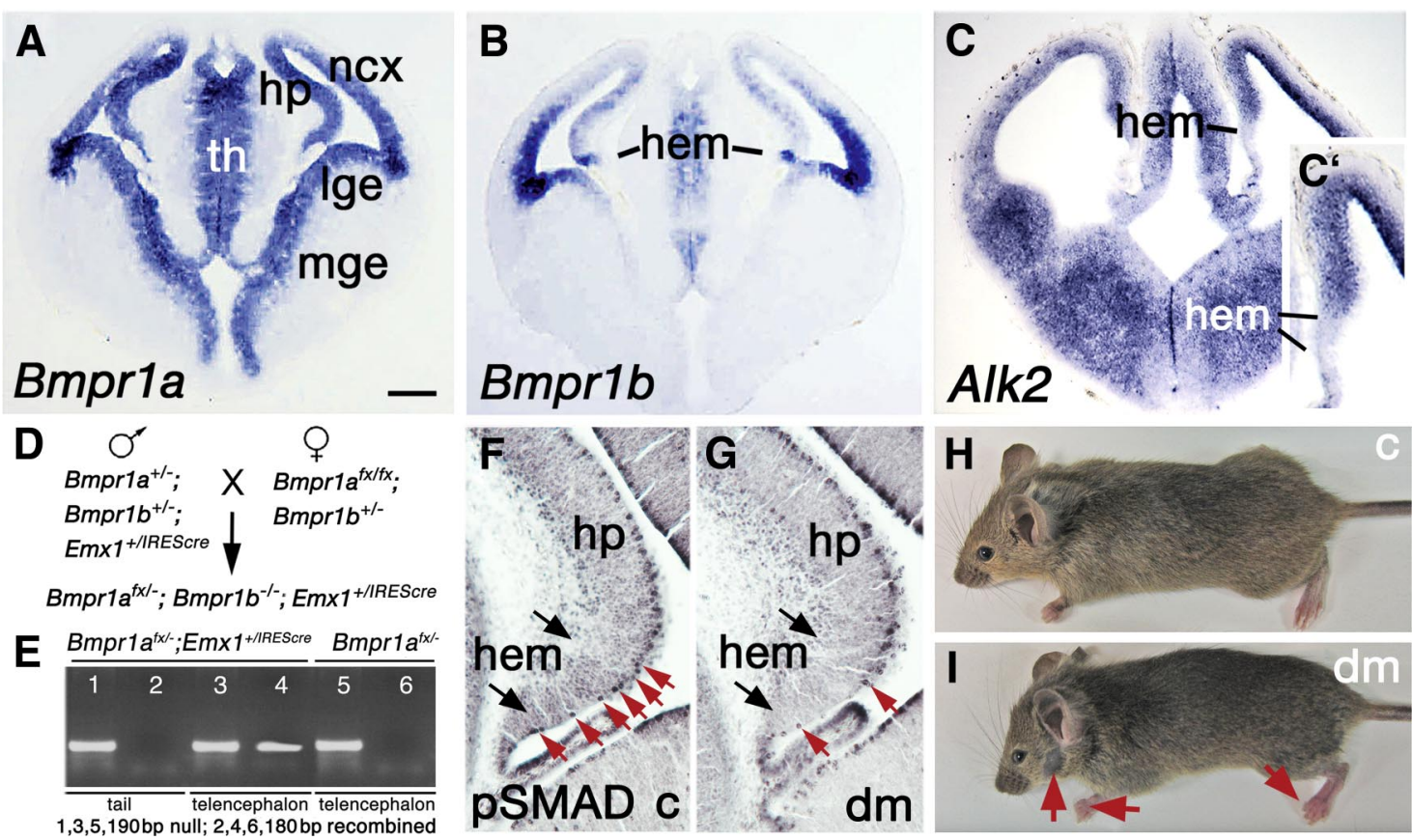

Figure 1. Generating double mutant mice deficient in Bmpr 1a and Bmpr $1 b$. A-C, Coronal sections through the telencephalon of control mice at E11.5, processed with in situ hybridization to show expression of Bmpr1a $(\boldsymbol{A}), B m p r 1 b(\boldsymbol{B})$, and a third type I BMP receptor gene, Alk2 (C). Bmpr1a is expressed throughout the telencephalic neuroepithelium including the cortical hem; Bmpr $1 b$ is expressed more selectively in the dorsal telencephalon with a hot spot of expression at the hem; $A / k 2$ is expressed broadly in the dorsal and ventral telencephalon, but not in the cortical hem ( $\boldsymbol{C}$, $\boldsymbol{C}^{\prime}$ ). D, Breeding strategy used to generate mice lacking Bmpr $1 b$ constitutively and Bmpr $1 a$ conditionally, the Bmpr $1 a^{f x /-} ; B m p r 1 b^{-1-} ; E m \times 1^{+/ I R E S c r e}$ double mutant genotype. E, PCR analysis of DNA extracted from the tail and telencephalon of E12.5 Bmpr1 $a^{f_{x} /-} ; E m \times 1{ }^{+/ I R E S c r e}$ and Bmpr1 $a^{f x /-}$ mice. Primers fx1 and fx4 (Mishina et al., 2002) amplified a $180 \mathrm{bp}$ fragment from Bmpr1 $a^{f_{x} /-}$; $E m \times 1^{+/ / R E S c r e}$ telencephalon (lane 4), indicative of Cre-mediated recombination of Bmpr1 $a^{f x}$. The $180 \mathrm{bp}$ "recombined" band was not amplified from tail tissue (lane 2) or Bmpr1 $a^{f \times /}$ telencephalon (lane 6). Primers $\mathrm{fx} 3$ and $\mathrm{fx} 5$ amplified a $190 \mathrm{bp}$ fragment from the Bmpr $1 a$ constitutive null allele in all three tissue samples (lanes 1, 3, 5). $\boldsymbol{F}, \mathbf{G}$, Coronal sections through the hem region at E12.5

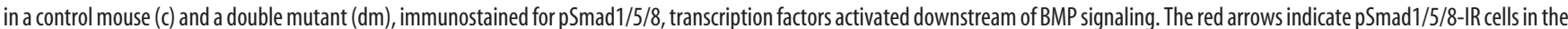
control hem $(\boldsymbol{F})$ but virtually no pSmad1/5/8-IR cells in the double mutant hem $(\boldsymbol{G})$. Outside the hem, in the hippocampal primordium, pSmad1/5/8-IR cells are dense along the ventricular surface $(\boldsymbol{F}, \boldsymbol{G}) . \boldsymbol{H}, \boldsymbol{I}$, A young adult control mouse $(\boldsymbol{H})$ and littermate double mutant $(\boldsymbol{I})$. The double mutant is slightly smaller than the control; the red arrows indicate truncated digits and partial loss of facial hair (see Results). Abbreviations: hem, Cortical hem; hp, hippocampus; Ige, lateral ganglionic eminence; mge, medial ganglionic eminence; $n c x$, neocortex; th, thalamus. Scale bar: (in $\boldsymbol{A}$ ) $\boldsymbol{A}-\boldsymbol{C}$, 200 $\mu \mathrm{m} ; \boldsymbol{C}^{\prime}, 100 \mu \mathrm{m} ; \boldsymbol{F}, \mathbf{G}, 50 \mu \mathrm{m}$.

(percentage of entries into the open arms compared with total number of entries), and open arm time ratio (time spent in open arms divided by total time spent in the arms). An entry was scored when all four limbs entered the box. Timing of the duration of an open arm entry started on entry and was terminated when one limb left the arm.

Startle reactivity. Testing was as previously described (Dulawa et al., 1997). Startle stimulus was a $40 \mathrm{~ms}$ broadband $120 \mathrm{~dB}$ burst. Amplitude of the startle response was recorded in $651 \mathrm{~ms}$ readings/stimulus.

Delayed alternation in a T-maze. There were 10 trials in the spatial alternation test. On trial 1, both arms were baited. On subsequent trials, a food pellet was given for entering the arm not visited on the previous run. Animals had $15 \mathrm{~s}$ to eat the pellet; the next trial began after 5, 30, or $60 \mathrm{~s}$.

Analysis of behavioral tests. Twenty-four mice used for behavioral testing had the following genotypes: Bmpr1 $a^{f x /-} ; B m p r 1 b^{-1-} ; E m x 1^{+/ I R E S c r e}$

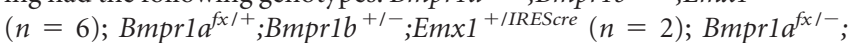
$B m p r 1 b^{+/-} ; E m x 1^{+/ I R E S c r e}(n=5) ; B m p r 1 a^{f x /+} ; B_{m p r l b}{ }^{+/-} \quad(n=$ 2); Bmpr1a $a^{f x /+} ; B m p r 1 b^{+/+} ; E m x 1^{+/ I R E S c r e}(n=4) ; B m p r 1 a^{f x /+}$; Bmprlb $^{-/-}(n=1) ; B$ Bmprla $a^{f x /+} ; B_{\text {mprlb }}{ }^{+/+}(n=4)$. An initial control group for comparison with the double mutants $(n=6)$ was formed of single heterozygote animals and Bmprl $a^{f x /+} ; B \operatorname{Bmprlb} b^{+/+}$mice $(n=10)$. However, a second group of mice $(n=8)$ with more severe genotypes comprising Bmprlb deletion, double heterozygosity, and Bmprla conditional deletion plus Bmprlb heterozygosity, did not differ significantly from the initial control group in contextual $(p=0.13)$ or cued $(p=0.5)$ fear learning, or on the EPM open-arm index $(p=0.7)$ (one-tailed $t$ tests). For this reason, mice of all genotypes other than double mutants were pooled in the final control group. ANOVA was used to test for significant differences between means. For most behavioral tests, a oneway ANOVA (with genotype as the factor) was used. The exception was the MWM, which was analyzed by repeated-measures ANOVA. Statistical tests were run using NCSS software.

Because a Cre allele can occasionally disrupt development and behavior as a result of effects on the gene locus into which Cre is inserted or Cre toxicity (Shen et al., 2006; Naiche and Papaioannou, 2007), we compared two groups of control mice: those that carried a Cre allele $(n=11)$ and those that did not $(n=7)$. The two groups did not differ significantly in performance measures on the EPM test $(p>0.6)$. We therefore found no evidence that the presence of Cre itself contributed to the behavioral phenotype described in double mutant mice.

The number of double mutants available for behavioral testing was restricted because of low fertility and low probability of the doublemutant genotype. For this reason, all behavioral tests were run on the same two groups of double mutants and controls. A concern was that differential postfear conditioning stress levels might influence the behavior of double mutants and controls in the EPM. Greater retention of conditioned fear might cause higher general stress, resulting in increased anxiety in the EPM. Linear correlation (NCSS) was used to test the hypothesis that freezing time in the cued fear retention test covaried with the open-arm index score in the EPM, consistent with an influence of postfear conditioning stress on behavior in the EPM. Control mice showed no significant correlation, failing to support the hypothesis.

\section{Results}

Loss of BMPR1a and BMPR1b function in

double mutant mice

BMPs are produced by the embryonic telencephalic roofplate, cortical hem, and developing CPe (Furuta et al., 1997; Grove et 
al., 1998), and at least three BMP type I receptors are expressed in the cortical primordium (Fig. $1 A-C$ ). Bmprla is expressed throughout the telencephalic ventricular zone (VZ), whereas Bmpr1b expression is more confined to the dorsal and lateral telencephalon (Fig. 1A,B). Alk2, a third BMP type I receptor gene, also known as Acvr1, is also expressed in the telencephalon (Fig. 1C) and was not deleted in the present study. Strikingly, only Alk2 expression is absent from the cortical hem (Fig. 1C, $C^{\prime}$ ). An implication is that the cortical hem may be particularly vulnerable to the loss of both BMPR1a and BMPR1b, given the lack of potential functional compensation by the ALK2 receptor. To test this possibility, we examined immunoreactivity for phosphorylated Smad transcription factors (pSmad1/5/8 immunoreactivity), which transduce BMP signaling (Chen et al., 2004). Our findings support the hypothesis that loss of BMPR1a and BMPR1b function has a marked effect on the hem. Virtually no pSmad1/5/8-IR cells were detected in the hem of double mutants, compared with many immunoreactive cells in the hem of control mice (Fig. $1 F, G$, red arrows). Outside the hem, dense pSmad1/5/8-IR cells appeared along the ventricular surface in both double mutants and controls (Fig. $1 F, G$ ).

To generate double Bmprla/Bmprlb mutant mice, Bmprlb was deleted constitutively (Yi et al., 2000), and Bmprla was deleted conditionally using null and floxed alleles of Bmprla (Mishina et al., 1995, 2002) and an Emxl(IRES)Cre line (Gorski et al., 2002) (Fig. 1D). Emx1(IRES)Cre-mediated recombination of the Bmpr1 $a^{f x}$ allele was confirmed in the telencephalon by PCR (Fig. 1E). Thus, from E9.5 onward, both BMP receptor genes were lost from a similar region of the forebrain: the neocortical and hippocampal primordia and the cortical hem. Because the breeding scheme used to generate the $B m p r 1 a^{f x /-} ; B m p r 1 b^{-1-}$; Emx $1^{+ \text {IIREScre }}$ genotype (Fig. $1 D$ ) did not give rise to true wildtype mice, littermate controls used in neuroanatomical analyses of Bmprla $a^{f x /-} ; B m p r 1 b^{-1-} ; E m x 1^{+/ I R E S c r e}$ mice were animals that were singly or doubly heterozygous for Bmprla and Bmpr1b, or that carried one wild-type and one floxed Bmprla allele.

Mice of the Bmprla $a^{f x /-} ; B m p r 1 b^{-/-} ; E m x 1^{+/ I R E S c r e}$ genotype were slightly smaller than littermate controls (Fig. $1 H, I$ ), although brain size was unchanged (supplemental Fig. S1, available at www.jneurosci.org as supplemental material). Despite the broad expression of Bmprlb in the body and brain (Yi et al., 2000), the most prominent reported feature of the Bmprlb null mouse is a truncation of the digits of both limbs, particularly evident in the hindlimb (Yi et al., 2000). Bmpr1 $a^{f x /-} ; B m p r 1 b^{-1-}$; Emx $1^{+/ I R E S c r e}$ displayed digit truncation as expected, indicating constitutive loss of Bmprlb function (Fig. 1I). A previous study revealed that Emx1(IRES)Cre-mediated recombination occurring outside the developing brain led to defects in facial structure (Yoshida et al., 2006). Interestingly, given a previous report that BMPR1a signaling is implicated in differentiation and growth of
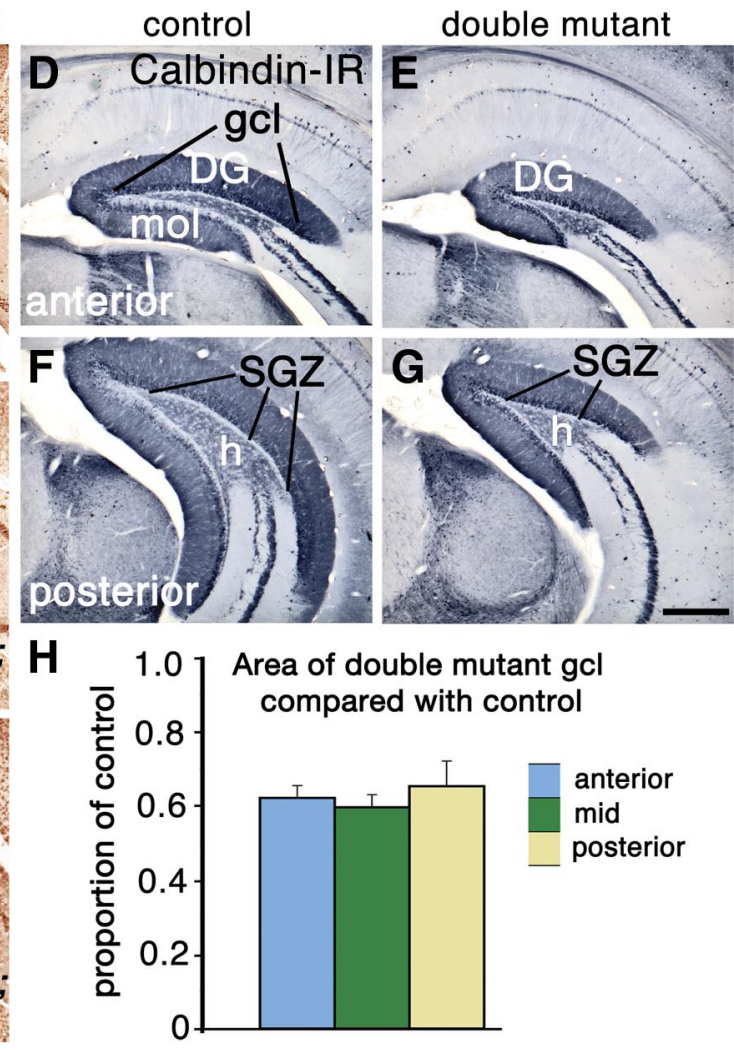

Figure 2. Loss of function of two BMP receptor genes leads to a reduced DG. $\boldsymbol{A}-\mathbf{G}$, Coronal sections through the hippocampus

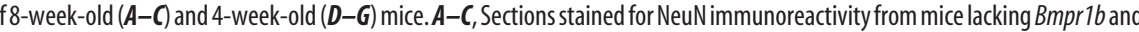
$\mathrm{gcl}$ in double mutants is $\sim 60 \%$ of that in control mice; this proportion is not significantly different at anterior, mid, or posterior levels of the DG. Data are represented as means \pm SEM. Scale bar: (in $\mathbf{G}) \boldsymbol{A}-\mathbf{G}, 375 \mu \mathrm{m}$.

hair follicles (Andl et al., 2004), the double mutant mouse displayed a partial loss of hair on the face (Fig. 1I). Limb truncation and facial hair loss were also seen, respectively, in single Bmpr $1 b$ and single Bmprla mutants (data not shown). Both phenotypic analysis and PCR analysis of recombination therefore demonstrated loss of function of BMPR1a and BMPR1b in mice of the Bmpr1 ${ }^{f x /-} ; B m p r 1 b^{-1-} ; E m x 1^{+/ I R E S c r e}$ genotype.

\section{The dentate gyrus granule cell layer is selectively reduced in} double mutant mice

With one exception, overall brain anatomy was grossly normal in double mutant mice (supplemental Fig. S1, available at www. jneurosci.org as supplemental material). The exception was in the hippocampus, composed of the CA fields and the DG. Double mutant mice showed an abnormally small DG (Fig. 2). In contrast, the CA fields appeared normal in size (supplemental Figs. S2, S3, available at www.jneurosci.org as supplemental material).

A reduced DG was seen only in double mutant mice, not in mice lacking either functional Bmprla or Bmprlb alone, or animals additionally lacking one functional copy of the other Bmpr 1 gene (Fig. 2A-C). Thus, BMPR1a and BMPR1b receptors compensate for one another in DG development: a single functional copy of either Bmpr1a or Bmprlb rescues normal DG size.

The area of the gcl in coronal section was quantified and compared between 8 -week-old double mutants and controls $(n=$ 3/group) as described in Materials and Methods. The two groups 


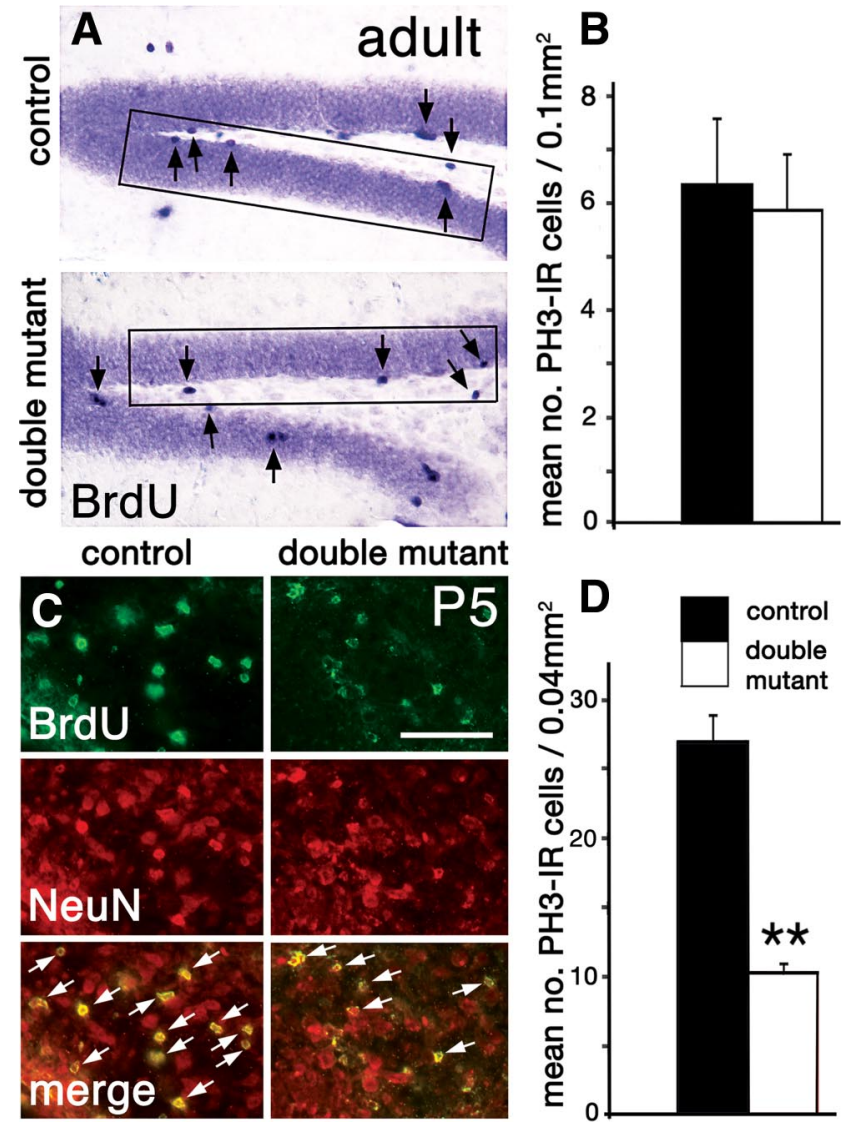

Figure 3. A reduced DG is associated with a drop in neonatal but not adult neurogenesis. $\boldsymbol{A}, \boldsymbol{B}$, Proliferating cells labeled with immunohistochemistry for BrdU ( $\boldsymbol{A}$, arrows) or $\mathrm{PH} 3$ in 8-week-old brains. BrdU-IR cells appear equally dense in the SGZ and hilus in control and double mutant brains $(\boldsymbol{A})$. The rectangles in $\boldsymbol{A}$ indicate field size used for counting BrdU-IR and PH3-IR cells. $\boldsymbol{B}$, Density of PH3-IR cells in the SGZ of control and double mutant brains ( $n=3$, each group) is not significantly different. $\boldsymbol{C}$, Coronal sections through the DG hilus at P5 processed with double immunofluorescence for BrdU and the neuronal marker NeuN. Double immunofluorescence (merge) labels twice as many newborn neurons in the DG hilus of a control mouse than a double mutant (the white arrows indicate double-positive cells). $\boldsymbol{D}$, Density of PH3-IR cells in the hilus of neonatal control and double mutant brains ( $n=3$, each group). The density of mitotic cells was significantly less in double mutants ( $p=0.003$, one-tailed $t$ test). Data are represented as means \pm SEM. ${ }^{* *} p<0.01$. Scale bar: (in $\boldsymbol{C}$ ) $\boldsymbol{A}, 100 \mu \mathrm{m} ; \boldsymbol{C}, 50 \mu \mathrm{m}$.

were significantly different ( $p=0.003$ ), and the mean area of the gcl in double mutants was 0.62 of that in controls (Fig. $2 H$ ). Because anatomical and neurochemical features of the hippocampus differ along its septal to temporal axis (approximately anterodorsal to posteroventral in the mouse or rat) (Fanselow and Dong, 2010), the proportional decrease in gcl area was compared among binned sections representing the anterior, middle, and posterior thirds of the DG (Fig. $2 H$ ). No significant differences were found.

\section{All layers of the DG are proportionally reduced in double mutants}

Corresponding with the smaller gcl, the molecular layer of the DG, which contains the dendrites of granule cells and afferent axons, was reduced compared with control brains, as was the hilus, the interior, polymorphic region of the DG, and the SGZ (Fig. 2D-G). The SGZ contains cells that continue to proliferate throughout life, generating new granule neurons for the DG (Kaplan and Hinds, 1977; Kaplan and Bell, 1984; Eckenhoff and Rakic, 1988; Eriksson et al., 1998; Kornack and Rakic, 1999). The

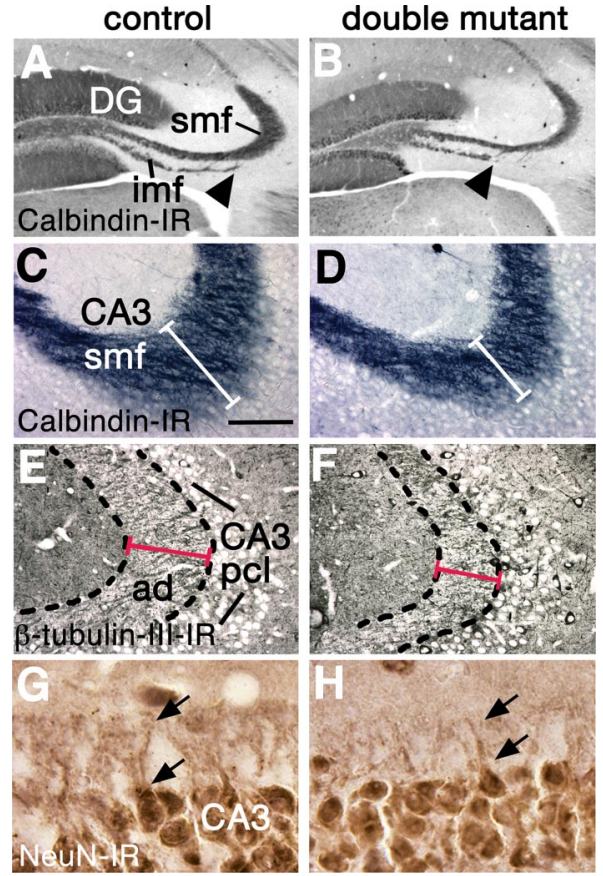

Figure 4. The projection from the $D G$ to $C A 3$ is abnormal in double mutants. $\boldsymbol{A}-\boldsymbol{H}$, Coronal sections through 8-week-old brains, processed for calbindin $(\boldsymbol{A}-\boldsymbol{D})$ class III $\beta$-tubulin $(\boldsymbol{E}, \boldsymbol{F})$ or NeuN immunoreactivity $(\boldsymbol{G}, \boldsymbol{H}) . \boldsymbol{A}-\boldsymbol{D}$, In double mutant brains, the infrapyramidal mossy fiber bundle (imf) is truncated $(\boldsymbol{A}, \boldsymbol{B}$, arrowheads), and the intrapyramidal and suprapyramidal mossy fibers (grouped as smf) are reduced ( $\boldsymbol{A}-\boldsymbol{D}$, white bars in $\boldsymbol{C}, \boldsymbol{D})$. $\boldsymbol{E}-\boldsymbol{H}$, The stratum lucidum of the hippocampus $(\boldsymbol{E}, \boldsymbol{F}$, broken outline) is filled with mossy fiber-recipient apical dendrites (ad) of $C A 3$ neurons. CA3 apical dendrites are shorter in double mutants compared with controls $(\boldsymbol{E}, \boldsymbol{F}$, red lines); the arrows indicate the proximal parts of the apical dendrites of two neurons in $\boldsymbol{G}$ and $\boldsymbol{H}$. Abbreviation: pcl, Pyramidal cell layer. Scale bar: (in $\boldsymbol{C}) \boldsymbol{A}, \boldsymbol{B}, 300 \mu \mathrm{m} ; \boldsymbol{C}-\boldsymbol{F}, 75 \mu \mathrm{m}$; $\mathbf{G}, \mathbf{H}, 30 \mu \mathrm{m}$.

density of proliferating cells in the double mutant SGZ was not significantly different from that in the control SGZ (Fig. 3A,B). Thus, the size of the adult stem cell niche in the double mutant appeared proportional to the overall smaller size of the DG.

Few apoptotic cells were detected in the DG of adult double mutants or controls (0.3 labeled cells/field). Levels of adult neurogenesis and neuron survival therefore maintained the smaller size of the DG in the double mutant but did not alter it further as the animal grew older.

The hilus contains excitatory mossy cell neurons, which are born at the same time as the first granule neurons and share with granule cells several aspects of their development (Li et al., 2008). Consistent with this close developmental association, the number of mossy cells, identified as large neurons with prominent processes immunoreactive for calretinin ( $\mathrm{Li}$ et al., 2008), was reduced by $25 \%$ in double mutants compared with control mice (supplemental Fig. S2, available at www.jneurosci.org as supplemental material).

\section{A smaller mossy fiber projection to CA3 in adult} double mutants

The mossy fiber projection from the DG gcl to CA3 represents the major extrinsic output of the DG. In double mutant mice, mossy fiber bundles were reduced (Fig. $4 A-D$ ), and the apical dendrites of CA3 neurons, which receive mossy fiber input, were shorter than in controls (Fig. 4E-H), indicating that dendritic morphology responded to diminished input from the DG. Our findings therefore indicate that all layers of the DG, two of its major cell types, its adult stem cell niche, and its extrinsic output to CA3 


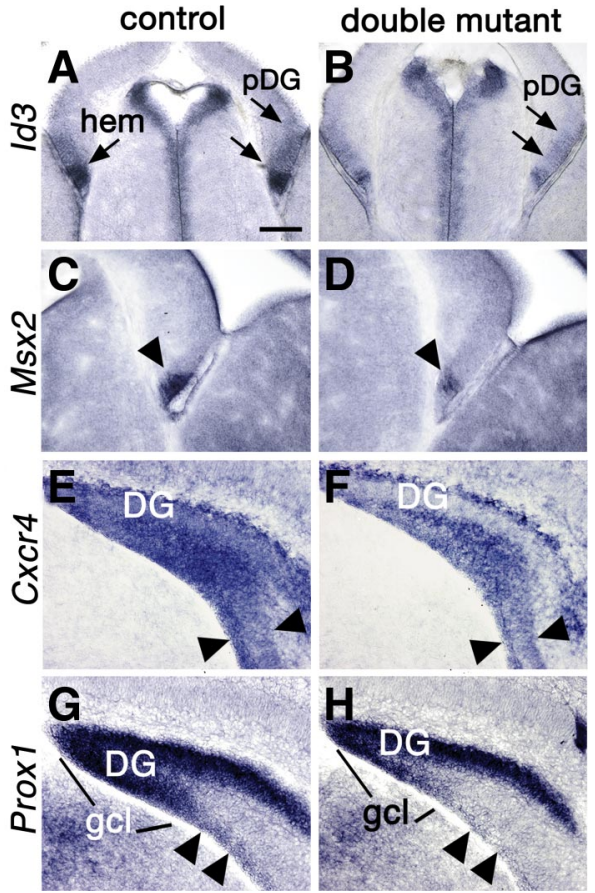

Figure 5. DG development is disrupted from its inception. $\boldsymbol{A}-\boldsymbol{H}$, Coronal sections through the telencephalon processed for in situ hybridization. $\boldsymbol{A}-\boldsymbol{D}, \mathrm{E} 14.5 . \boldsymbol{E}-\boldsymbol{H}, \mathrm{PO} . \boldsymbol{A}-\boldsymbol{D}$, The pDG and hem express lower levels of $I d 3$ and $M s \times 2$, genes upregulated by BMP signaling, in a double mutant $(\boldsymbol{B}, \boldsymbol{D})$ compared with a control $(\boldsymbol{A}, \boldsymbol{C})$. The pDG domain is indicated with double arrows $(\boldsymbol{A}, \boldsymbol{B})$. $\boldsymbol{E}-\boldsymbol{H}$, The secondary $\mathrm{DG}$ progenitor cell pool migrates toward the forming $D G$, together with differentiating DG neurons. Both cell types express $C x c r 4$, and differentiating neurons express Prox1. Expression of $\mathrm{Cxcr} 4$ in the double mutant brain indicates a narrower band of migratory cells $(\boldsymbol{E}, \boldsymbol{F}$, arrowheads), and expression of Prox 1 reveals a greatly reduced population of migrating, differentiating $D G$ neurons ( $\boldsymbol{G}, \boldsymbol{H}$, arrowheads). Scale bar: (in $\boldsymbol{A}) \boldsymbol{A}, \boldsymbol{B}, 150 \mu \mathrm{m}$; $\mathbf{C}-\mathbf{H}, 100 \mu \mathrm{m}$

were reduced in double mutant mice. These observations suggested that the DG, and neural circuitry that includes the DG, would be functionally compromised.

\section{DG development in double mutant mice is disrupted from its inception}

The generation of DG granule neurons is prolonged (Altman and Bayer, 1990a,b; Pleasure et al., 2000; Bagri et al., 2002; Li and Pleasure, 2005). From approximately E10.5 to E15.5 in mice, part of the telencephalic VZ close to the cortical hem contains the primary DG progenitor pool, the pDG. By E16, secondary DG progenitors migrate from the VZ close to the pial surface, toward the future site of the DG. After migration, a prolific tertiary pool in the hilus of the DG generates the majority of granule neurons in the first postnatal week. The stem cell niche that will continue into adulthood arises from the tertiary DG progenitor pool as progenitor cells relocate to the SGZ (Li and Pleasure, 2005).

By E14.5, in control mice, the pDG domain expressed Id3 (Pleasure et al., 2000) (Fig. 5A), and the adjacent hem region expressed Id 3 and $M s x 2$, direct targets of BMP signaling (von Bubnoff et al., 2005). Both genes were downregulated in double mutants, indicating reduced BMP signaling (Fig. $5 A-D$ ). In particular, compared with controls, remaining $I d 3$ expression outlined a smaller pDG domain (Fig. 5A,B, paired arrows). Additional evidence for reduced BMP signaling in the hem was provided by an abnormally small telencephalic CPe at E12.5, which arises from the hem (Louvi et al., 2007) at this age, and
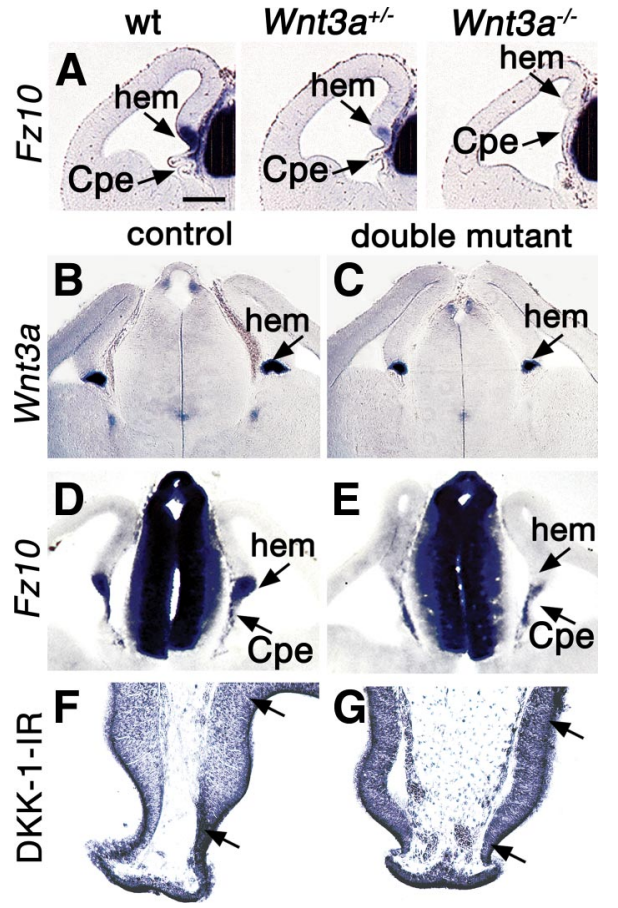

Figure 6. Defects of Wnt signaling in the cortical hem. $\boldsymbol{A}-\mathbf{G}$, Coronal sections through the E12.5 telencephalon processed for in situ hybridization. $A$, Expression of $F z 10$ in wild type (wt) and heterozygous and homozygous Wnt3a mutant brains. Fz10 expression fills the wild-type hem and appears in patches in the (Pe; expression is weaker in the heterozygous Wnt3a mutant hem and absent from the homozygous mutant hem. $\boldsymbol{B}-\boldsymbol{E}$, The hem shows a smaller domain of Wnt3a expression in a double mutant compared with a control brain $(\boldsymbol{B}, \boldsymbol{C})$ and greatly reduced expression of $F z 10(\boldsymbol{D}, \boldsymbol{E}) . \boldsymbol{F}, \boldsymbol{G}$, A region (between arrows) including the hem and $\mathrm{pDG}$ shows immunoreactivity for a Wnt antagonist, DKK1. DKK1 immunoreactivity is more intense in this region in the double mutant (G) than in the control (F). Scale bar: (in $\boldsymbol{A}) \boldsymbol{A}-\boldsymbol{E}, 200 \mu \mathrm{m} ; \boldsymbol{F}$, G, $100 \mu \mathrm{m}$.

requires BMP signaling for its formation (Panchision et al., 2001; Hébert et al., 2002; Imayoshi et al., 2008).

At $\mathrm{P} 0$, in control mice, secondary DG progenitors, migrating toward the forming DG, expressed Cxcr4, a chemokine receptor gene, as did migrating, differentiating DG neurons (Bagri et al., 2002; Lu et al., 2002). Expression of the prospero homeobox gene, Proxl, labeled differentiating granule neurons along the same migratory path (Bagri et al., 2002; Lu et al., 2002). In double mutant mice, the Cxcr4 expressing migratory stream was narrower than in control mice (Fig. $5 E, F$, double arrows), indicating a diminished secondary DG progenitor pool, and Proxl-expressing postmitotic neurons were virtually absent from the pathway (Fig. 5G,H).Proxl expression already outlined a smaller DG in the double mutant at $\mathrm{P} 0$ (Fig. 5G,H).

The most pronounced difference between control and double mutant mice appeared in the first week after birth, when proliferation in the tertiary progenitor pool peaks. A single BrdU injection $24 \mathrm{~h}$ before killing at P5 resulted in a profusion of hilar cells double-labeled for BrdU and the neuronal marker, NeuN, in control mice. Approximately one-half as many double-positive cells were seen in the hilus of double mutants (Fig. 3C, merge, white arrows). Cell proliferation was quantified, with mitotic cells identified by immunoreactivity for the phosphorylated form of histone $\mathrm{H} 3$ ( $\mathrm{PH} 3$ immunoreactivity), and was significantly different between controls and double mutants ( $p=0.003$ ) (Fig. $3 D$ ). Rates of neonatal apoptosis, determined by counting cells immunoreactive for caspase-3, were low and statistically indistinguishable between mutants and controls (0.5-1 cell/field). The 
smaller DG seen in the adult double-mutant mouse was therefore attributable to early postnatal reduction of granule cell generation and not increased cell death.

Our observations suggest a progression of developmental defects that leads to a reduced DG. Diminished primary and secondary DG progenitor pools lead sequentially to a smaller tertiary pool in double mutant mice. The smaller tertiary pool in turn leads to a reduced DG, and to the allocation of fewer cells to the adult stem cell niche, which is established by approximately P10 (Li and Pleasure, 2005).

\section{BMP regulation of cortical hem Wnt signaling}

A survey of the expression of Fz and sFrp Wnt receptor and inhibitor genes in Wnt3a mutant mice (M. Yoshida and E. A. Grove, unpublished results) demonstrated that the level of Fz10 expression at the hem correlates with Wnt3a gene dosage. Fz10 expression was reduced in mice heterozygous for a null Wnt3a allele, and absent in homozygous Wnt3a mutants at E12.5 (Fig. 6A). Fz10 expression therefore appears to be regulated by Wnt3a and to act as a readout of $W n t 3 a$ expression and Wnt3a activity within the hem at this age.

In the double mutant cortical hem at E12.5, Wnt3a expression was somewhat decreased, but expression of Fz10 was virtually gone (Fig. 6B-E). The relatively modest decrease in Wnt $3 a$ expression does not predict the near absence of Fz10 expression; the latter suggests a considerable loss of Wnt3a function in the hem. Potentially explaining this discrepancy, immunoreactivity for the Wnt inhibitor, DKK1 (Glinka, 1998), was increased in double mutants in the hem and the region of the pDG at E12.5 (Fig. $6 F, G$, between arrows). Increased inhibition by DKK1 of an already low level of Wnt3a signaling could explain the unexpectedly dramatic loss of Fz10 hem expression.

Previous studies show that abrogating Wnt3a signaling results in loss of the entire hippocampus (Galceran et al., 2000; Lee et al., 2000). Reduction of Wnt signaling, as in Lef1 and LRP6 mutants, spares the CA fields and selectively affects the DG (Galceran et al., 2000; Zhou et al., 2004; Li and Pleasure, 2005). Together, present and previous observations therefore indicate that the reduced size of the double mutant DG is at least partly attributable to lower Wnt signaling from the hem.

Double mutants are deficient in fear learning and display less anxiety than controls

We asked whether reducing BMP signaling in the developing telencephalon has behavioral consequences, focusing on behaviors associated with the hippocampus. General activity levels were tested first because the shortened digits of double mutant mice could affect locomotion and because neonatal hippocampal ablation may cause hyperactivity (McHugh et al., 2004). No significant differences were found in activity levels between control and double mutant mice in the home cage test $(p=0.7)$ or in distance traveled or rearing activity in the open-field test $(p=0.8$ for both).

The rodent hippocampus has been classically implicated in the consolidation of memory and formation of spatial maps (Squire, 1987). A commonly used test of spatial learning and memory is the MWM (Morris, 1981, 1984). No significant differences were found between controls and double mutants in learning to find a hidden platform in the MWM, or in time spent in the platform quadrant during a final "probe" trial. This result was not unexpected, however, given that a deficit in MWM performance requires the loss of $>20 \%$ of total hippocampal volume (Moser et al., 1993). The decrease in the size of the DG in double mutants

\section{A Conditioned fear learning}

Freezing before and after foot shock

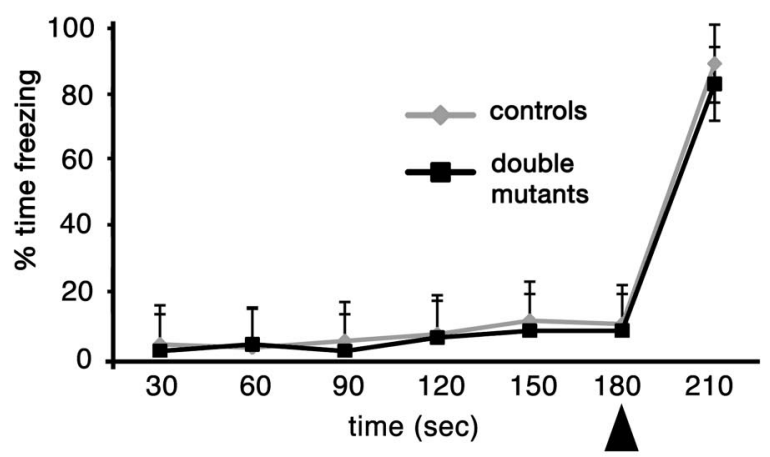

Conditioned fear memory

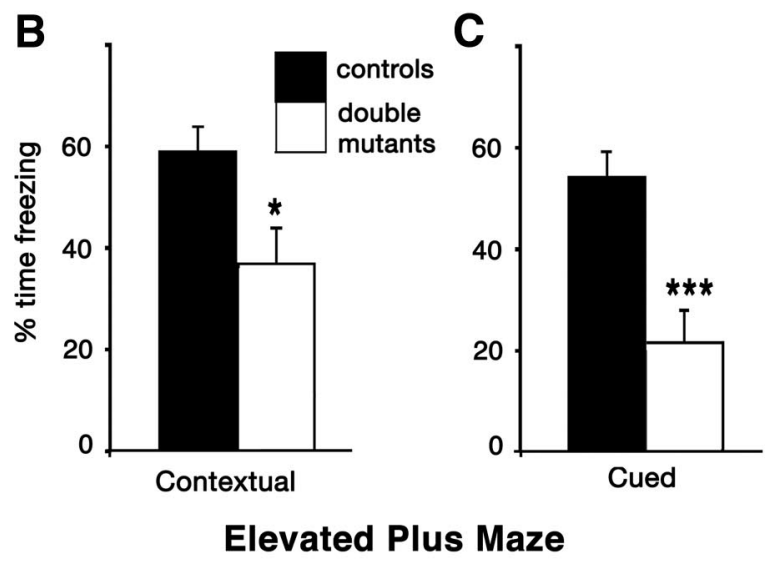

D Time in Open Arms
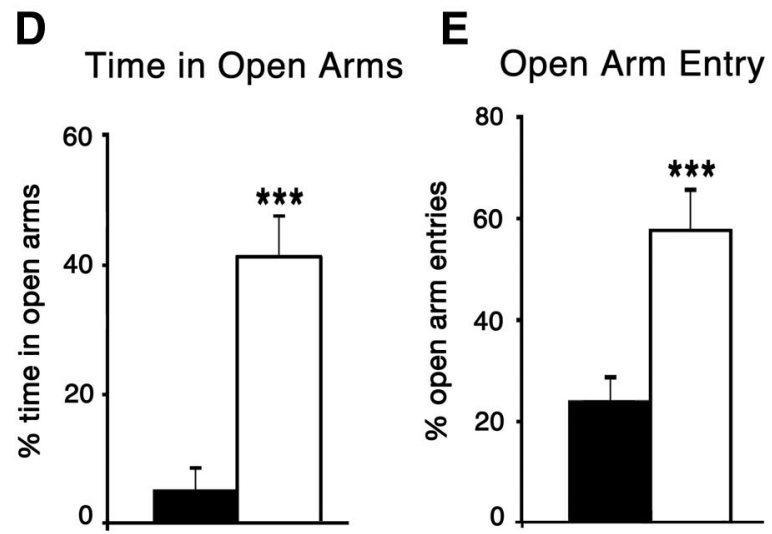

Figure 7. Double mutant mice show diminished fear conditioning and lower anxiety. $\boldsymbol{A}$, Freezing behavior in the shock chamber preceding the $2 \mathrm{~s}$ footshock (arrowhead) and for $30 \mathrm{~s}$ afterward. Freezing behavior did not differ in the training trial between double mutants and control mice. $\boldsymbol{B}, \boldsymbol{C}$, Double mutant mice showed significantly reduced responses in retention tests of contextual and cued fear learning. Tested $24 \mathrm{~h}$ after the single conditioning trial, doublemutant mice froze significantly less than control mice in response to the conditioned stimulus (contextual, $p=0.04$; cued, $p=0.0008$ ). $\boldsymbol{D}, \boldsymbol{E}$, In an elevated plus maze, double mutant mice spent significantly more time in the open arms than did control mice ( $p=0.0007)$ and made more open arm entries as a percentage of total entries ( $p=0.0008)$. There was no significant difference in the number of total entries between the two groups $(p=0.7)$. ${ }^{*} p<0.05$; ${ }^{* * *} p<0.001$. Data are represented as means \pm SEM.

would not reach this threshold. Lack of impaired performance in double mutants, however, underscored the normal mobility of these mice.

In contrast, double mutant and control mice differed significantly in a test of contextual fear learning, also associated with 
hippocampal function. Each mouse was placed into a training chamber, where a tone preceded a mild footshock. Memory was tested for the training context by returning each mouse to the same chamber next day and measuring the time spent freezing. Double mutants froze significantly less than controls $(p=0.04)$ (Fig. $7 B$ ).

Placing mice in a novel chamber, and delivering the same tone as on the previous training day, tested fear conditioning cued by the tone. Cued fear conditioning is more commonly associated with the amygdala than the hippocampus (Squire, 1987; LeDoux, 2000). Nonetheless, double mutant mice also froze significantly less than controls to the tone alone $(p=0.0008)$ (Fig. $7 C)$. A hearing impairment in double mutants was discounted by their normal performance in an acoustic startle test.

To test the hypothesis that decreased performance in both fear-conditioning tasks was caused by reduced fear or anxiety, double mutant mice were exposed to an innately anxiety provoking environment, the EPM. Walls enclose two arms of the EPM, but two arms are open with a drop on either side. Mice face a conflict between their drive to explore and their innate aversion to open spaces. The amount of time spent in the open arms is taken as an inverse measure of anxiety (Pellow et al., 1985). Control mice tended to avoid the open arms, but double mutants did not (Fig. $7 D, E$ ). Supporting the hypothesis, therefore, doublemutant mice showed reduced fear responses, whether these responses were learned or innate.

Suggesting that lowered responsiveness was specific for aversive stimuli, double mutant mice behaved normally in seeking a positive reward. In a delayed alternation T-maze task, double mutants showed robust reward-seeking behavior and working memory, with no significant difference between controls and double mutants $(p=0.6)$.

Only double mutant mice, and not other mutant genotypes, showed fear conditioning deficits and lowered anxiety in the EPM. Behavior in the EPM was not significantly different, for example, between controls and mice that lacked Bmprla and were heterozygous for $B m p 1 b(p>0.4)$. Thus, as previously observed, BMPR1a and BMPR1b receptors compensate for one another: a single functional copy of Bmprlb in this context rescues normal fear-related behavior, as well as normal DG size. Additionally, the normal phenotype of Bmpr1 $a^{f x /-} ; B m p r 1 b^{+/-}$; Emx1 $1^{+/ I R E S c r e}$ mice (Bmprla null; Bmpr1b heterozygous), compared with Bmpr1a ${ }^{f x /-} ; B m p r 1 b^{-1-} ; E m x 1^{+/ I R E S c r e}$ mice (double mutants) implies that the presence of the Cre allele did not itself affect DG size or the behavioral measures assessed (see also Materials and Methods).

At least some previously identified effects of reducing BMP signaling in the brain can be discounted as a cause of altered fear and anxiety responsiveness in double mutant mice. For example, deleting Bmpr1a conditionally in cells expressing Olig1 alters the number of cortical oligodendrocytes and calbindin-expressing interneurons (Samanta et al., 2007). As noted, however, we found that mice lacking Bmpr1a did not show the behavioral abnormalities observed in double mutants. Furthermore, although deletion of both Bmprla and Bmprlb causes a transient increase in somatostatin containing cortical interneurons, this effect is no longer seen at the age at which double mutants were tested (Mukhopadhyay et al., 2009).

\section{BMP signaling in the telencephalon regulates fear responsiveness}

Behavioral studies were initiated to test the effects of a reduced DG on learning and memory. Somewhat unexpectedly, we found that double mutant mice showed greatly decreased fear and anxiety responses in a variety of tasks. These observations indicate that BMP signaling is required to regulate fear-related behavior. Furthermore, this requirement is specific to the telencephalon, given that hypothalamic and brainstem nuclei involved in fear and anxiety lie outside the range of Emx1-IRES-Cre-mediated recombination (Gorski et al., 2002) (M. Yoshida and E. A. Grove, unpublished observations).

Telencephalic structures that lie in the domain of the Emx1 lineage and have been implicated in fear behavior are the hippocampus (Barkus et al., 2010), the basolateral (BLA) and lateral (LA) nuclei of the amygdala (Vazdarjanova and McGaugh, 1999; McGaugh, 2004; LeDoux, 2007; Jimenez and Maren, 2009), and areas of neocortex, such as prefrontal cortex, which mediates fear extinction (Sotres-Bayon et al., 2006). Of these, the amygdala is most strongly associated with fear learning (Vazdarjanova and McGaugh, 1999; McGaugh, 2004; LeDoux, 2007; Jimenez and Maren, 2009). We therefore sought evidence that the primary defect causing altered fear and anxiety behavior lay outside the DG.

A detailed neuroanatomical survey revealed no defects in the BLA, LA, hippocampal CA fields, or neocortex (supplemental Figs. S1, S3-S5, available at www.jneurosci.org as supplemental material). This survey evaluated the size, shape, and gene expression patterns of the LA and BLA in maturity and development, and the cholinergic and catecholaminergic innervation of the amygdala, critical to its role in fear-related behavior (Dalmaz et al., 1993; Power and McGaugh, 2002). Neocortex, including the dorsomedial cingulate and retrosplenial areas, appeared similar in double mutants and controls with respect to size, laminar pattern indicated by gene expression patterns and visible area boundaries. In particular, detailed layer patterning in prefrontal cortex appeared identical between double mutants and control mice (supplemental Fig. S5, available at www.jneurosci.org as supplemental material). It should be emphasized that the results of this survey do not preclude subtle changes resulting from reduced BMP signaling, which were not seen with anatomical methods and which, in turn, could cause functional deficits. Notably, however, the same region of rodent prefrontal cortex implicated in fear extinction is also associated with working memory (Heidbreder and Groenewegen, 2003; Dalley et al., 2004), and a test of working memory indicated no difference in performance between controls and double mutant mice. Our cellular and molecular analysis of the brain in double mutants therefore points to the DG as the prime candidate for mediating the behavioral abnormalities of these mice.

\section{Discussion}

\section{BMP signaling promotes generation of dorsal}

\section{telencephalic neurons}

DG granule cells are the most dorsal neuronal lineage in the telencephalon, with their primary progenitor cells immediately next to the dorsal telencephalic source of BMPs (Altman and Bayer, 1990a,b; Pleasure et al., 2000). Our observations therefore demonstrate that BMP signaling is required in the telencephalon, as in the caudal CNS (Liem et al., 1995, 1997; Nguyen et al., 2000; Timmer et al., 2002; Wine-Lee et al., 2004), for a full complement of dorsal neurons.

Our findings indicate a developmental progression in the DG, initiated by BMP signaling, that leads to proportional numbers of granule neurons, mossy cells, and cells for the adult stem cell niche. We propose that, in double mutant mice, a reduced allocation of neuroepithelial cells to the primary DG progenitor pool leads to smaller secondary and tertiary progenitor pools. The 
smaller tertiary pool gives rise to a reduced number of DG neurons, and fewer cells are allocated to the adult stem cell niche. The particular effect of reduced BMP signaling on the adult stem cell population that we observed is not likely to be ongoing. In the adult mouse, BMPs block expansion of the SGZ neural stem cell pool, whereas Noggin, a BMP inhibitor, expands it (Bonaguidi et al., 2008; Tang et al., 2009).

\section{BMP signaling regulates Wnt signaling in the cortical hem}

$\mathrm{BMP}$ regulation of the hem appears to be a prime mechanism by which BMP signaling controls development of the DG. We found evidence of greatly decreased Wnt3a activity in the hem itself, and by inference, in neighboring tissues that normally receive a Wnt3a signal from the hem. Single Bmpr1a and Bmprlb mutants also show decreased Wnt3a function (data not shown), but less prominently than double mutants. Consistent with these findings, in mice with an earlier embryonic loss of Bmprlb and Bmprla than in the present study, expression of $W n+3 a$ and $W n t 2 b$ is virtually absent in the presumptive hem (Fernandes et al., 2007). Present and previous observations therefore indicate that BMP signaling is required, both early and late in corticogenesis, to induce and maintain the expression of Wnt signaling in the cortical hem.

\section{BMP signaling and dorsal cell type induction in the neural tube}

In the spinal cord, where the patterning effects of BMP signaling on the CNS have been most thoroughly studied, raised levels of BMP signaling increase the dorsalmost neuronal populations at the expense of more ventral populations, and decreased levels of BMP signaling have the opposite effect (Liem et al., 1995, 1997; Nguyen et al., 2000; Timmer et al., 2002; Wine-Lee et al., 2004). Moreover, different cell populations change size without corresponding alterations in cell proliferation, suggesting that BMP signaling does not influence cell proliferation in the dorsal spinal cord, but rather the fate of dorsal cell populations (Liem et al., 1995, 1997; Timmer et al., 2002; Wine-Lee et al., 2004).

We found no evidence for cell fate changes in the hippocampus of double mutant mice. Adjacent to the smaller DG, the CA fields appear normal in size. Responses to decreased BMP signaling in the developing hippocampus resemble, instead, those seen in the cerebellum (Qin et al., 2006). Loss of function of BMP type I receptors leads to a large reduction of cerebellar granule cells, with no apparent defects in the specification of cerebellar Purkinje cells (Qin et al., 2006). Reduction of cerebellar granule cells is associated with a decrease in cell proliferation (Qin et al., 2006), similar to our findings that the reduced DG granule neuron population in double mutants is associated with reduced proliferation in the tertiary DG progenitor pool.

\section{The telencephalic phenotype of double mutant mice appears highly selective}

The region of Emxl(IRES)Cre-induced Cre-lox recombination includes most of the dorsal telencephalon, and double mutant mice might have been expected to show more extensive anatomical defects. Nonetheless, we found no overt abnormalities in the double mutant brain outside the dorsal midline of the telencephalon and propose three factors to explain this phenotype. First, structures that develop adjacent to the dorsal telencephalic BMP source may require the highest levels of BMP signaling and therefore be most vulnerable to reduced signaling. Second, selective overlap between Bmprla expression and Emx1(IRES)Cremediated recombination left functional Bmprla in much of the brain. Third, BMP signaling was not completely abrogated in the double mutant telencephalon. With the notable exception of the cortical hem, a third type I BMP receptor, ALK2, is present in the telencephalon from embryogenesis into adulthood (Allen Mouse Brain Atlas) (Lein et al., 2007) (Fig. 1; supplemental Fig. S4, available at www.jneurosci.org as supplemental material). Activation of ALK2 may account for the broad pSmad1/5/8 immunoreactivity observed in both adult control and double mutant brains, which suggests significant BMP signaling in both (supplemental Fig. S4, available at www.jneurosci.org as supplemental material). The cortical hem, which lacks ALK2, together with structures that are dependent on the hem, are therefore particularly vulnerable to combined deficiency in Bmprla and Bmprlb. These dorsal telencephalic structures, the hem, choroid plexus epithelium, and DG, were indeed those with obvious defects in double mutant mice.

\section{Potential role for the DG in neural circuitry mediating fear and anxiety}

The DG is the single structure that shows an overt anatomical defect in the double mutant brain. Moreover, lower levels of fear and anxiety, and a reduced DG, both correlate with the doublemutant genotype, and with none of the other BmprI mutant genotypes assessed. Previous studies have directly associated the DG with anxiety-related behavior. Loss of NMDA receptor activity in the DG (Niewoehner et al., 2007; Barkus et al., 2010), or the DG and CA1 (von Engelhardt et al., 2008; Barkus et al., 2010), reduces anxiety in the successive alleys test, a modified EPM (Niewoehner et al., 2007).

Inputs to the DG further support a link between the DG and the modulation of fear and anxiety. Afferents to the DG include the densest noradrenergic innervation of any part of the hippocampus (Amaral and Witter, 1995), serotonergic input from the raphe nuclei, and a projection from the supramammillary region (Amaral and Witter, 1995; Leranth and Hajszan, 2007). Ablating or reversibly silencing the supramammillary region reduces fear responses in rodents (Pan and McNaughton, 2002; Aranda et al., 2006).

The association of a part of the hippocampus with fear has a precedent, in that large lesions of the rodent ventral hippocampus, but not dorsal hippocampus, diminish responsiveness to fear-provoking stimuli whether the association with fear is learned or innate (Moser and Moser, 1998; Kjelstrup et al., 2002; Bannerman et al., 2004; Fanselow and Dong, 2010). Our analysis suggests that the DG is smaller throughout the double mutant hippocampus with no greater reduction in the ventral hippocampus. However, the packing density of granule neurons is normally higher in rodents at dorsal than at ventral levels of the hippocampus (Amaral and Witter, 1995), potentially making the ventral hippocampus more vulnerable to DG cell loss. Finally, a connection between the hippocampus and fear is conserved across distantly related mammals. Monkeys with large hippocampal lesions (no attempt was made to ablate the ventral or dorsal hippocampus selectively) show little fear of toy snakes, an innately fear-provoking stimulus (Chudasama et al., 2008).

\section{Conclusions}

We find that BMP signaling is required to allocate the proper number of DG progenitor cells in early hippocampal development, a process that appears at least partly mediated by Wnt signaling from the cortical hem. As a result of decreased BMP signaling, several cell types of the DG, including the stem cell niche that provides new neurons in adulthood, as well as the 
overall laminar structure of the DG, are proportionally reduced. We further find that BMP signaling in the telencephalon regulates fear-related behaviors. The specific locus of the dysfunction remains to be confirmed, using conditional gene deletions specific to the amygdala, the cortical hem, or the developing DG, an approach that is not yet available. Current evidence, however, supports the DG as a strong candidate for this role and contributes to previous findings that implicate the hippocampus in emotional as well as cognitive behaviors.

\section{References}

Ahn K, Mishina Y, Hanks MC, Behringer RR, Crenshaw EB 3rd (2001) BMPR-IA signaling is required for the formation of the apical ectodermal ridge and dorsal-ventral patterning of the limb. Development 128:44494461.

Altman J, Bayer SA (1990a) Mosaic organization of the hippocampal neuroepithelium and the multiple germinal sources of dentate granule cells. J Comp Neurol 301:325-342.

Altman J, Bayer SA (1990b) Migration and distribution of two populations of hippocampal granule cell precursors during the perinatal and postnatal periods. J Comp Neurol 301:365-381.

Amaral DG, Witter MP (1995) Hippocampal formation. In: The rat nervous system, Ed 2 (Paxinos G, ed), pp 443-493. San Diego: Academic.

Andl T, Ahn K, Kairo A, Chu EY, Wine-Lee L, Reddy ST, Croft NJ, CebraThomas JA, Metzger D, Chambon P, Lyons KM, Mishina Y, Seykora JT, Crenshaw EB 3rd, Millar SE (2004) Epithelial Bmprla regulates differentiation and proliferation in postnatal hair follicles and is essential for tooth development. Development 131:2257-2268.

Aranda L, Santín LJ, Begega A, Aguirre JA, Arias JL (2006) Supramammillary and adjacent nuclei lesions impair spatial working memory and induce anxiolitic-like behavior. Behav Brain Res 167:156-164.

Bagri A, Gurney T, He X, Zou YR, Littman DR, Tessier-Lavigne M, Pleasure SJ (2002) The chemokine SDF1 regulates migration of dentate granule cells. Development 129:4249-4260.

Bannerman DM, Rawlins JN, McHugh SB, Deacon RM, Yee BK, Bast T, Zhang WN, Pothuizen HH, Feldon J (2004) Regional dissociations within the hippocampus-memory and anxiety. Neurosci Biobehav Rev 28:273-283.

Baquet ZC, Gorski JA, Jones KR (2004) Early striatal dendrite deficits followed by neuron loss with advanced age in the absence of anterograde cortical brain-derived neurotrophic factor. J Neurosci 24:4250-4258.

Barkus C, McHugh SB, Sprengel R, Seeburg PH, Rawlins JN, Bannerman DM (2010) Hippocampal NMDA receptors and anxiety: at the interface between cognition and emotion. Eur J Pharmacol 626:49-56.

Beeler JA, Prendergast B, Zhuang X (2006) Low amplitude entrainment of mice and the impact of circadian phase on behavior tests. Physiol Behav 87:870-880.

Bonaguidi MA, Peng CY, McGuire T, Falciglia G, Gobeske KT, Czeisler C, Kessler JA (2008) Noggin expands neural stem cells in the adult hippocampus. J Neurosci 28:9194-9204.

Chen D, Zhao M, Mundy GR (2004) Bone morphogenetic proteins. Growth Factors 22:233-241.

Cheng X, Hsu CM, Currle DS, Hu JS, Barkovich AJ, Monuki ES (2006) Central roles of the roof plate in telencephalic development and holoprosencephaly. J Neurosci 26:7640-7649.

Chudasama Y, Wright KS, Murray EA (2008) Hippocampal lesions in rhesus monkeys disrupt emotional responses but not reinforcer devaluation effects. Biol Psychiatry 63:1084-1091.

Cocas LA, Miyoshi G, Carney RS, Sousa VH, Hirata T, Jones KR, Fishell G, Huntsman MM, Corbin JG (2009) Emx1-lineage progenitors differentially contribute to neural diversity in the striatum and amygdala. J Neurosci 29:15933-15946.

Dalley JW, Cardinal RN, Robbins TW (2004) Prefrontal executive and cognitive functions in rodents: neural and neurochemical substrates. Neurosci Biobehav Rev 28:771-784

Dalmaz C, Introini-Collison IB, McGaugh JL (1993) Noradrenergic and cholinergic interactions in the amygdala and the modulation of memory storage. Behav Brain Res 58:167-174.

Dulawa SC, Hen R, Scearce-Levie K, Geyer MA (1997) Serotonin1B receptor modulation of startle reactivity, habituation, and prepulse inhibition in wild-type and serotonin1B knockout mice. Psychopharmacology (Berl) 132:125-134.

Eckenhoff MF, Rakic P (1988) Nature and fate of proliferative cells in the hippocampal dentate gyrus during the life span of the rhesus monkey. J Neurosci 8:2729-2747.

Eriksson PS, Perfilieva E, Björk-Eriksson T, Alborn AM, Nordborg C, Peterson DA, Gage FH (1998) Neurogenesis in the adult human hippocampus. Nat Med 4:1313-1317.

Fanselow MS, Dong HW (2010) Are the dorsal and ventral hippocampus functionally distinct structures? Neuron 65:7-19.

Fernandes M, Gutin G, Alcorn H, McConnell SK, Hébert JM (2007) Mutations in the BMP pathway in mice support the existence of two molecular classes of holoprosencephaly. Development 134:3789-3794.

Furuta Y, Piston DW, Hogan BL (1997) Bone morphogenetic proteins (BMPs) as regulators of dorsal forebrain development. Development 124:2203-2212.

Galceran J, Miyashita-Lin EM, Devaney E, Rubenstein JL, Grosschedl R (2000) Hippocampus development and generation of dentate gyrus granule cells is regulated by LEF1. Development 127:469-482.

Glinka A, Wu W, Delius H, Monaghan AP, Blumenstock C, Niehrs C (1998) Dickkopf- 1 is a member of a new family of secreted proteins and functions in head induction. Nature 391:357-362.

Gorski JA, Talley T, Qiu M, Puelles L, Rubenstein JL, Jones KR (2002) Cortical excitatory neurons and glia, but not GABAergic neurons, are produced in the Emx1-expressing lineage. J Neurosci 22:6309-6314.

Gorski JA, Balogh SA, Wehner JM, Jones KR (2003) Learning deficits in forebrain-restricted brain-derived neurotrophic factor mutant mice. Neuroscience 121:341-354.

Grailhe R, Waeber C, Dulawa SC, Hornung JP, Zhuang X, Brunner D, Geyer MA, Hen R (1999) Increased exploratory activity and altered response to LSD in mice lacking the 5- $\mathrm{HT}_{5 \mathrm{~A}}$ receptor. Neuron 22:581-591.

Grove EA, Tole S, Limon J, Yip L, Ragsdale CW (1998) The hem of the embryonic cerebral cortex is defined by the expression of multiple Wnt genes and is compromised in Gli3-deficient mice. Development 125:2315-2325.

Hébert JM, Mishina Y, McConnell SK (2002) BMP signaling is required locally to pattern the dorsal telencephalic midline. Neuron 35:1029-1041.

Hébert JM, Hayhurst M, Marks ME, Kulessa H, Hogan BL, McConnell SK (2003) BMP ligands act redundantly to pattern the dorsal telencephalic midline. Genesis 35:214-219.

Heidbreder CA, Groenewegen HJ (2003) The medial prefrontal cortex in the rat: evidence for a dorso-ventral distinction based upon functional and anatomical characteristics. Neurosci Biobehav Rev 27:555-579.

Imayoshi I, Shimogori T, Ohtsuka T, Kageyama R (2008) Hes genes and neurogenin regulate non-neural versus neural fate specification in the dorsal telencephalic midline. Development 135:2531-2541.

Jamin SP, Arango NA, Mishina Y, Hanks MC, Behringer RR (2002) Requirement of Bmprla for Mullerian duct regression during male sexual development. Nat Genet 32:408-410.

Jimenez SA, Maren S (2009) Nuclear disconnection within the amygdala reveals a direct pathway to fear. Learn Mem 16:766-768.

Kaplan MS, Bell DH (1984) Mitotic neuroblasts in the 9-day-old and 11month-old rodent hippocampus. J Neurosci 4:1429-1441.

Kaplan MS, Hinds JW (1977) Neurogenesis in the adult rat: electron microscopic analysis of light radioautographs. Science 197:1092-1094.

Kjelstrup KG, Tuvnes FA, Steffenach HA, Murison R, Moser EI, Moser MB (2002) Reduced fear expression after lesions of the ventral hippocampus. Proc Natl Acad Sci U S A 99:10825-10830.

Kornack DR, Rakic P (1999) Continuation of neurogenesis in the hippocampus of the adult macaque monkey. Proc Natl Acad Sci U S A 96:5768-5773

LeDoux J (2007) The amygdala. Curr Biol 17:R868-R874.

LeDoux JE (2000) Emotion circuits in the brain. Annu Rev Neurosci 23:155-184.

Lee SM, Tole S, Grove E, McMahon AP (2000) A local Wnt-3a signal is required for development of the mammalian hippocampus. Development 127:457-467.

Lein ES, Hawrylycz MJ, Ao N, Ayres M, Bensinger A, Bernard A, Boe AF, Boguski MS, Brockway KS, Byrnes EJ, Chen L, Chen L, Chen TM, Chin MC, Chong J, Crook BE, Czaplinska A, Dang CN, Datta S, Dee NR, et al. (2007) Genome-wide atlas of gene expression in the adult mouse brain. Nature 445:168-176 
Leranth C, Hajszan T (2007) Extrinsic afferent systems to the dentate gyrus. Prog Brain Res 163:63-84.

Li G, Pleasure SJ (2005) Morphogenesis of the dentate gyrus: what we are learning from mouse mutants. Dev Neurosci 27:93-99.

Li G, Berger O, Han SM, Paredes M, Wu NC, Pleasure SJ (2008) Hilar mossy cells share developmental influences with dentate granule neurons. Dev Neurosci 30:255-261.

Li HS, Wang D, Shen Q, Schonemann MD, Gorski JA, Jones KR, Temple S, Jan LY, Jan YN (2003) Inactivation of Numb and Numblike in embryonic dorsal forebrain impairs neurogenesis and disrupts cortical morphogenesis. Neuron 40:1105-1118.

Liem KF Jr, Tremml G, Roelink H, Jessell TM (1995) Dorsal differentiation of neural plate cells induced by BMP-mediated signals from epidermal ectoderm. Cell 82:969-979.

Liem KF Jr, Tremml G, Jessell TM (1997) A role for the roof plate and its resident TGFbeta-related proteins in neuronal patterning in the dorsal spinal cord. Cell 91:127-138.

Louvi A, Yoshida M, Grove EA (2007) The derivatives of the Wnt3a lineage in the central nervous system. J Comp Neurol 504:550-569.

Lu M, Grove EA, Miller RJ (2002) Abnormal development of the hippocampal dentate gyrus in mice lacking the CXCR4 chemokine receptor. Proc Natl Acad Sci U S A 99:7090-7095.

Machon O, Backman M, Machonova O, Kozmik Z, Vacik T, Andersen L, Krauss S (2007) A dynamic gradient of Wnt signaling controls initiation of neurogenesis in the mammalian cortex and cellular specification in the hippocampus. Dev Biol 311:223-237.

Mangale VS, Hirokawa KE, Satyaki PR, Gokulchandran N, Chikbire S, Subramanian L, Shetty AS, Martynoga B, Paul J, Mai MV, Li Y, Flanagan LA, Tole S, Monuki ES (2008) Lhx2 selector activity specifies cortical identity and suppresses hippocampal organizer fate. Science 319:304-309.

McGaugh JL (2004) The amygdala modulates the consolidation of memories of emotionally arousing experiences. Annu Rev Neurosci 27:1-28.

McHugh SB, Deacon RM, Rawlins JN, Bannerman DM (2004) Amygdala and ventral hippocampus contribute differentially to mechanisms of fear and anxiety. Behav Neurosci 118:63-78.

Mishina Y, Suzuki A, Ueno N, Behringer RR (1995) Bmpr encodes a type I bone morphogenetic protein receptor that is essential for gastrulation during mouse embryogenesis. Genes Dev 9:3027-3037.

Mishina Y, Hanks MC, Miura S, Tallquist MD, Behringer RR (2002) Generation of Bmpr/Alk3 conditional knockout mice. Genesis 32:69-72.

Morris RG (1981) Spatial localization does not require the presence of local cues. Learn Motiv 12:239-260.

Morris RG (1984) Developments of a water-maze procedure for studying spatial learning in the rat. J Neurosci Methods 11:47-60.

Moser E, Moser MB, Andersen P (1993) Spatial learning impairment parallels the magnitude of dorsal hippocampal lesions, but is hardly present following ventral lesions. J Neurosci 13:3916-3925.

Moser MB, Moser EI (1998) Functional differentiation in the hippocampus. Hippocampus 8:608-619.

Mukhopadhyay A, McGuire T, Peng CY, Kessler JA (2009) Differential effects of BMP signaling on parvalbumin and somatostatin interneuron differentiation. Development 136:2633-2642.

Naiche LA, Papaioannou VE (2007) Cre activity causes widespread apoptosis and lethal anemia during embryonic development. Genesis 45:768775 .

Nguyen VH, Trout J, Connors SA, Andermann P, Weinberg E, Mullins MC (2000) Dorsal and intermediate neuronal cell types of the spinal cord are established by a BMP signaling pathway. Development 127:1209-1220.

Niewoehner B, Single FN, Hvalby Ø, Jensen V, Meyer zum Alten Borgloh S, Seeburg PH, Rawlins JN, Sprengel R, Bannerman DM (2007) Impaired spatial working memory but spared spatial reference memory following functional loss of NMDA receptors in the dentate gyrus. Eur J Neurosci 25:837-846.

Ovchinnikov DA, Selever J, Wang Y, Chen YT, Mishina Y, Martin JF, Behringer RR (2006) BMP receptor type IA in limb bud mesenchyme regulates distal outgrowth and patterning. Dev Biol 295:103-115.

Pan WX, McNaughton N (2002) The role of the medial supramammillary nucleus in the control of hippocampal theta activity and behaviour in rats. Eur J Neurosci 16:1797-1809.

Panchision DM, Pickel JM, Studer L, Lee SH, Turner PA, Hazel TG, McKay RD (2001) Sequential actions of BMP receptors control neural precursor cell production and fate. Genes Dev 15:2094-2110.

Paxinos G, Tork I, Tecott LH, Valentino KL (1991) Atlas of the developing rat brain. San Diego: Academic.

Pellow S, Chopin P, File SE, Briley M (1985) Validation of open:closed arm entries in an elevated plus-maze as a measure of anxiety in the rat. J Neurosci Methods 14:149-167.

Pleasure SJ, Collins AE, Lowenstein DH (2000) Unique expression patterns of cell fate molecules delineate sequential stages of dentate gyrus development. J Neurosci 20:6095-6105.

Power AE, McGaugh JL (2002) Cholinergic activation of the basolateral amygdala regulates unlearned freezing behavior in rats. Behav Brain Res 134:307-315.

Qin L, Wine-Lee L, Ahn KJ, Crenshaw EB 3rd (2006) Genetic analyses demonstrate that bone morphogenetic protein signaling is required for embryonic cerebellar development. J Neurosci 26:1896-1905.

Samanta J, Burke GM, McGuire T, Pisarek AJ, Mukhopadhyay A, Mishina Y, Kessler JA (2007) BMPR1a signaling determines numbers of oligodendrocytes and calbindin-expressing interneurons in the cortex. J Neurosci 27:7397-7407.

Shen L, Nam HS, Song P, Moore H, Anderson SA (2006) FoxG1 haploinsufficiency results in impaired neurogenesis in the postnatal hippocampus and contextual memory deficits. Hippocampus 16:875-890.

Sotres-Bayon F, Cain CK, LeDoux JE (2006) Brain mechanisms of fear extinction: historical perspectives on the contribution of prefrontal cortex. Biol Psychiatry 60:329-336.

Squire LR (1987) Memory and brain. New York: Oxford UP.

Takada S, Stark KL, Shea MJ, Vassileva G, McMahon JA, McMahon AP (1994) Wnt-3a regulates somite and tailbud formation in the mouse embryo. Genes Dev 8:174-189.

Tang J, Song M, Wang Y, Fan X, Xu H, Bai Y (2009) Noggin and BMP4 co-modulate adult hippocampal neurogenesis in the APP(swe)/ PS1(DeltaE9) transgenic mouse model of Alzheimer's disease. Biochem Biophys Res Commun 385:341-345.

Tang YP, Shimizu E, Dube GR, Rampon C, Kerchner GA, Zhuo M, Liu G, Tsien JZ (1999) Genetic enhancement of learning and memory in mice. Nature 401:63-69.

Timmer JR, Wang C, Niswander L (2002) BMP signaling patterns the dorsal and intermediate neural tube via regulation of homeobox and helix-loophelix transcription factors. Development 129:2459-2472.

Vazdarjanova A, McGaugh JL (1999) Basolateral amygdala is involved in modulating consolidation of memory for classical fear conditioning. J Neurosci 19:6615-6622.

von Bubnoff A, Peiffer DA, Blitz IL, Hayata T, Ogata S, Zeng Q, Trunnell M, Cho KW (2005) Phylogenetic footprinting and genome scanning identify vertebrate BMP response elements and new target genes. Dev Biol 281:210-226

von Engelhardt J, Doganci B, Jensen V, Hvalby Ø, Göngrich C, Taylor A, Barkus C, Sanderson DJ, Rawlins JN, Seeburg PH, Bannerman DM, Monyer H (2008) Contribution of hippocampal and extra-hippocampal NR2B-containing NMDA receptors to performance on spatial learning tasks. Neuron 60:846-860.

Wine-Lee L, Ahn KJ, Richardson RD, Mishina Y, Lyons KM, Crenshaw EB 3rd (2004) Signaling through BMP type 1 receptors is required for development of interneuron cell types in the dorsal spinal cord. Development 131:5393-5403.

Yi SE, Daluiski A, Pederson R, Rosen V, Lyons KM (2000) The type I BMP receptor BMPRIB is required for chondrogenesis in the mouse limb. Development 127:621-630.

Yoshida M, Assimacopoulos S, Jones KR, Grove EA (2006) Massive loss of Cajal-Retzius cells does not disrupt neocortical layer order. Development 133:537-545.

Zhou CJ, Zhao C, Pleasure SJ (2004) Wnt signaling mutants have decreased dentate granule cell production and radial glial scaffolding abnormalities. J Neurosci 24:121-126. 